\title{
Possible Causes of Health Disorders in Stored Yam at Farm Gate
}

\author{
Moomin Abu*, Kwara Francis Adzigiwe \\ Department of Horticulture, Faculty of Agriculture, University for Development Studies, Tamale, Ghana \\ Email: *moonabu@yahoo.com
}

How to cite this paper: $\mathrm{Abu}, \mathrm{M}$. and Adzigiwe, K.F. (2021) Possible Causes of Health Disorders in Stored Yam at Farm Gate. Agricultural Sciences, 12, 960-976.

https://doi.org/10.4236/as.2021.129062

Received: August 11, 2021

Accepted: September 6, 2021

Published: September 9, 2021

Copyright () 2021 by author(s) and Scientific Research Publishing Inc. This work is licensed under the Creative Commons Attribution International License (CC BY 4.0).

http://creativecommons.org/licenses/by/4.0/

\begin{abstract}
This study investigated and ascertained causes of health disorders in stored yam at farm gate in major yam producing communities in the Nanumba North District of Ghana. A mixed method research design was adopted for data collection through the application of Participatory Research Appraisal tools and techniques including individual interviews using questionnaires. Random sampling technique was used to select five communities and hundred respondents. Data was analyzed via descriptive statistics which generated summaries, Tables, histograms, and pie-charts using SAS software. Ages of respondents were in the range of 11 to over 60 years with illiterate majority. They were inadequate in their knowledge of agronomic, harvest, and postharvest practices and techniques including curing, chemical or botanical treatments for the yam tuber prior to storage. Fresh yam produce was kept in shallow dug trenches where temporal storage was the target but stored their dry yam produce intended for long periods in barns (most preferred) and on wooden platforms which were more sustainable with a little preponderance of the former. Causes of yam health disorders and associated problems in store were insect pests, rodents, weed pests, diseases (tuber rot), yam beetles, snakes, scorpions, and the inability of some storage structures to keep produce for a long time. Research, government, and other stakeholder institutions should partner up and make improved and certified yam sets accessible and affordable, and intensify agriculture extension services' interventions that empower farmers the knowledge on agronomic, harvest, and postharvest practices and techniques.
\end{abstract}

\section{Keywords}

Yam, Health Disorders, Storage, Farm Gate, Ghana

\section{Introduction}

Yam (Dioscorea species) is a perishable tropical crop plant that produces edible 
tubers rich in carbohydrates with low protein content. The major species are particularly indigenous to West Africa, and were the major sources of carbohydrate before the introduction of exotic crops including maize, rice, and cassava [1] [2]. Yam belongs to the genus Dioscorea which contains about 600 species [3] [4]. Of these species of the genus Dioscorea, Dioscorea rotundata (white yam), Dioscorea alata (water yam), Dioscorea cayenensis (yellow yam), Dioscorea bulbifera (aerial yam), Dioscorea esculenta (Chinese yam), and Dioscorea dumetorum (trifoliate yam) are cultivated in the light sandy soils of the interior savannah and in the forest zone of Ghana [5]. Besides the cultivated yam species, there are a number of wild types which are also harvested for food. The commonest of these is the Dioscorea praehensilis which is common in the forest belt.

The white yam, yellow yam, and water yam are the most important in West Africa as a source of food and are grown almost to the total exclusion of the rest except aerial yam which together with other minor species receive limited attention. The aerial yam and the Chinese yam are less important in the sub-region [6]. The white yam is the most widely cultivated [7] [8] and it is also the most popular. White yam is the principal commercial yam and constitutes about $80 \%$ of the total yam produced in Ghana. Water yam is also cultivated commercially in Ghana but to a lesser extent than the white yam [5] [7]. Few farmers grow yellow yam, aerial yam, Chinese yam, and trifoliate yam and it's mainly for home use. Zaknayiba and Tanko [9] noted that among the species, several varieties exist and Ackah et al. [5] observed that "Laribako" and "Puna" varieties of white yam are preferred and highly priced in Ghana. "Laribako" and "Puna" varieties have also been exported in Ghana (M. Abu, pers. Commun.) [10].

Kwara [11], Djana et al. [12], and earlier reports by FAO [13] indicated that factors that influence the choice of varieties of yam that farmers grow include consumer taste preference, maturity, storability, yield, adaptability, and availability and cost of planting materials. These sources also indicated that constraints to yam production include high labour demand for most cultural operations and other inputs such as planting materials, unreliable sources of credit, pests and diseases, declining soil fertility, and unpredictable weather conditions.

Even though current estimates of world-wide yam production output are far from complete or reliable [2], Africa is reported to have been responsible for about $95 \%$ of the world output with Nigeria remaining by far the largest producer in the continent. Ghana however remains the fourth largest producer. In Ghana, production growth rate for yam is projected to be $2.75 \%$ per annum [5]. The main centres of yam production in Ghana are the districts of Kwahu North (Eastern region); Sene, Kintampo, Atebubu, and Techiman (Brong-Ahafo region); Kete-Krachi and Nkwanta (Volta region); Ejura and Sekyedumase (Ashanti region); Salaga, Bimbila, and Sang (Northern region); and Wa and its environs (Upper West region). Yam is produced in many more districts but not in commercial quantities as in the named districts. Brong Ahafo, Northern, and Eastern 
regions are the high yam production areas in Ghana. The Brong Ahafo region is the leading producer of yam in Ghana both in terms of physical production and acreages cultivated. But the Nanumba North District yam production area of the northern region of Ghana hosts larger production of "Laribako" and "Puna" varieties of the white yam which have been reported to be preferred, highly priced, and exported in Ghana (M. Abu, pers. Commun.) [14].

Rees [14] reiterated that yam is the most important of the farm crops produced for home consumption in the internal economy of the people in the $\mathrm{Na}$ numba North district, and they also earn foreign exchange. Only one cropping season is possible during the year, and it is therefore necessary to store yam to cover the lack period and for other domestic and commercial purposes. It is also reported that there is under improvement of the yam crop; a situation that is accentuated by persistent deterioration as a result of lack of knowledge on the causes associated with yam health disorders [12]. Also, despite the fact that yam has an important role to play in meeting the food needs of the rapidly increasing human population and ensures food security in Ghana coupled with its income generating capability and export potential, very little attention has been given to its health care during storage. Farmers therefore continue to lose substantial parts of their stored produce as a result [11] [14].

In Ghana, the production and healthy storage of the perishable yam on both small and large scale 1) is an addition to other major carbohydrate containing crops such as maize, rice, and other root and tuber crops 2) generates jobs in the urban and peri-urban areas, 3) enhances the potential of horticultural crop export in Ghana, 4) may reduce foreign exchange requirements for imported carbohydrate-based foods, and 5) may also contribute positively to the National Poverty Reduction Drive [15] [16]. Yam is among the most important food crops and has economic and sociocultural importance in Ghana [2]. The fresh yam tuber contains an appreciable quantity of vitamins and minerals and it is also a source of industrial starch [9]. Yam's significant contribution to the food security in the sub-region has been well documented [3]. It serves as vital sources of calories especially in Bénin, Côte d'Ivoire, and Ghana. Yam also features prominently in social rites of passage, and thanks giving in the region. Its production is seasonal and the fresh tubers are highly perishable. Zaknayiba and Tanko [9] reiterated that postharvest losses are very high, ranging from $30 \%$ to $85 \%$ of the total production. In order to overcome this high perishability of the tuber and the irregularity of its availability throughout the year, investigating and making recommendation(s) for the development of technologies that result in improved/enhanced storage of each kilogram of yam becomes a necessity. This would greatly ameliorate problems faced by yam producing households, thus reinforcing food security and possible export. Hence, the need to investigate into and ascertain the possible cause(s) of health disorders encountered during storage of yam at farm gate in the Nanumba North district yam production zone in Ghana with the following objectives: 
1) to identify, sample, and determine the background of respondents,

2) to determine the types/varieties of yam cultivated and the associated production characteristics,

3) to assess the agronomic and harvesting practices (in relation to yam health),

4) to assess the storage and marketing technologies practiced (in relation to yam health) by the yam farmers.

\section{Methodology}

A survey was carried out in some selected major yam producing areas in the Nanumba North District of Ghana to investigate possible cause(s) of yam health disorders while in storage at farm gate. This was accomplished by administering questionnaires to the yam production sector of the yam industry in the study area. In all, hundred (100) respondents were interviewed.

\subsection{Study Area}

Nanumba North District in the northern region of Ghana is situated between $8^{\circ}$ and $11^{\circ} \mathrm{N}$ Latitude and $0^{\circ}-3^{\circ}$ West Longitude. The Northern Region is the largest region in Ghana, comprising $41 \%$ of Ghana's land area but has the lowest population density which is about $20 \%$ of the country's population [15]. About $80 \%$ of the people in the Northern region depend on farming for their livelihoods: rain fed agriculture is also predominant in the Northern region and the potential of irrigation is limited [16].

The areas surveyed for the study included five (5) communities (Jilo, Kpalga, Kpabi, Gangu yilli, and Pusuga) in the Nanumba North district of the northern region of Ghana. The Nanumba North District is one of the areas of the Northern Region where yam production is overwhelmingly carried out by almost every household. The natural vegetation of the area is typical of guinea savannah woodland that is composed of trees of varying sizes and density, dispersed in a ground cover of tall perennial bunch of grasses and associated herbs.

Soils are predominantly lateritic and mainly silt and sandy loam. There is a unimodal rainfall pattern in the Northern region of Ghana with quite a high annual variability and thus results in considerable drought risk. The study area is therefore characterized by distinct rainy and dry seasons in a year. Mean annual rainfall is approximately $1100 \mathrm{~mm}$ and constitutes over 95 rainy days in the season. The intensity of the rains builds up sparingly from March/April to a maximum in August and declines, coming to a complete stop in mid-November when the dry Saharan winds usher in the harmattan.

\subsection{Questionnaire Design}

In general, parameters considered in the questionnaire design included; in addition to bio-data and background of the yam farmers, socio-economic status of the farmers, agronomic and harvesting practices, and storage and marketing 
technologies practiced by the farmers as outlined by Casley and Lury [17].

\subsection{Sampling Area}

The study was carried out using randomly selected major yam producing communities (Jilo, Kpalga, Kpabi, Gangu yilli, and Pusuga) in the Nanumba North district. Twenty (20) respondents were randomly picked from each community for individual interviews using the transect method described by Zaknayiba and Tanko [9] since the communities were seemingly the same in size and the population was sparsely distributed. Twenty (20) respondents were interviewed for pre-testing and 100 respondents for the final survey.

\subsection{Questionnaire Administration}

The designed questionnaire was pretested at Jilo. Jilo is one of the communities randomly selected for the study. Data obtained were analyzed statistically and based on the results, modifications were made to the questionnaire and then administered to the randomly selected producers within the randomly selected communities. Data was collected from the different communities during expeditions through the application of Participatory Research Appraisal tools and techniques such as granary visits, direct observations, focus group discussions, and individual interviews using questionnaires and the help of translators from each area as outlined by Casley and Lury [17]. In each community, local farmers' associations were involved in the study to facilitate the identification of the farmers for the survey and for the data collection.

\subsection{Statistical Analysis}

Data was analyzed through descriptive statistics (frequencies, percentages, and means) to generate summaries, Tables, histograms, and pie charts at different communities'/individuals' levels using SAS [18] software.

\section{Results}

\subsection{Background of Respondents}

Age Range and Gender

The age ranges of the farmers were 11 - 20 years (4\%), 21 - 30 years (16\%), 31 40 years (34\%), $41-50$ years (30\%), $51-60$ years (12\%), and $>60$ years ( $4 \%)$. The majority fell within the age range of 31 - 40 years whiles the age ranges of $11-20$ $(4 \%)$ and $>60$ years $(4 \%)$ constituted the least. All respondents were males. Table 1 shows the age ranges of the respondents.

Forty four percent (44\%) of the farmers which represents majority were illiterates. Twenty six percent (26\%) of them acquired Middle School/Junior High School (JHS) education and eighteen percent (18\%) acquired Senior High School (SHS) education. Twelve percent (12\%) of them progressed to tertiary education level. Figure 1 shows the educational background of the farmers. 
Table 1. Age range of respondents.

\begin{tabular}{ccc}
\hline Age range (years) & Number of respondents & Percent respondent (\%) \\
\hline $11-20$ & 4 & 4 \\
$21-30$ & 16 & 16 \\
$31-40$ & 34 & 34 \\
$41-50$ & 30 & 30 \\
$51-60$ & 12 & 12 \\
$>60$ & 4 & 4 \\
Total & 100 & 100 \\
\hline
\end{tabular}

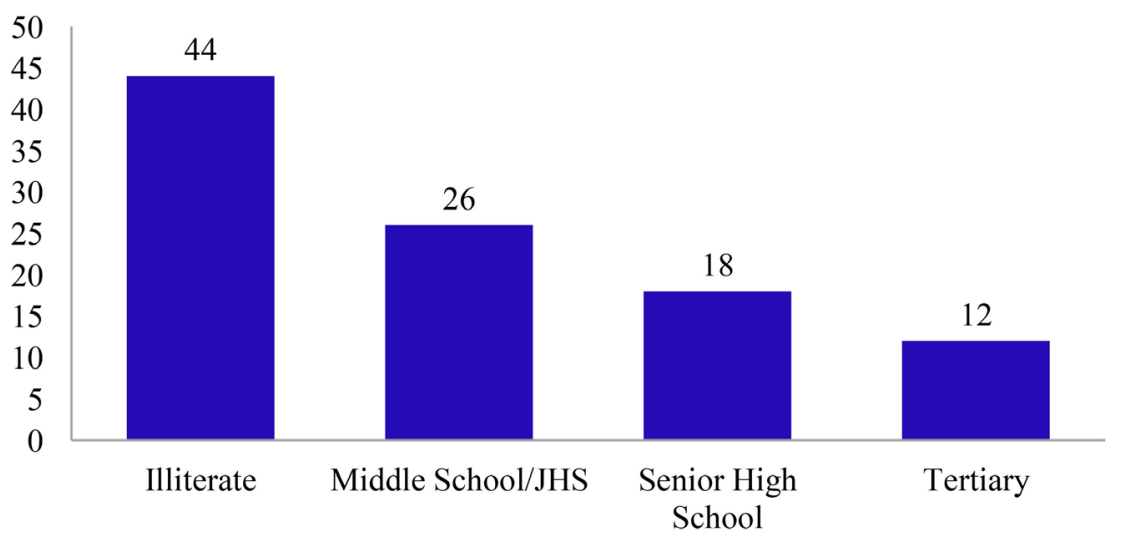

Figure 1. Educational level of respondents.

\subsection{Types/Varieties of Yam Grown and Associated Characteristics}

\subsubsection{Types/Varieties of Yam Grown}

Twelve (12) varieties (Laribako, Limo, Fuseini, Prinjo, Nawari (water yam), Alando, Akaba, Baatoo, Nyame-Nti, Afayili, Baffoo, and Pona) were discovered with Laribako, Fuseini, Alando, Prinjo, and Nawari being the most widely cultivated either alone or in combination with other varieties on the same farm. Cultivating one variety alone on the same farm was not common among the farmers' practices. Eight percent (8\%), six percent (6\%), two percent (2\%), three percent $(3 \%)$, and two percent (2\%) of them were recorded as cultivating Laribako, Fuseini, Alando, Nawari, and Prinjo, respectively, alone. The rest of the seventy nine percent (79\%) of the respondents cultivated Laribako, Fuseini, Alando, Nawari, and Prinjo in combination with other cultivars on the same farm. Figure 2 shows the varieties cultivated.

\subsubsection{Farmers' Sources of Finance for Yam Production}

The farmers' sources of finance for yam production were farmers' own money, money lenders, and bank loans. Majority (92\%) of the farmers used their own money in cultivating yam. Two percent $(2 \%)$ and six percent $(6 \%)$ of them got their financial support from money lenders and bank loans, respectively. Figure 3 shows the farmers' sources of finance for yam production. 


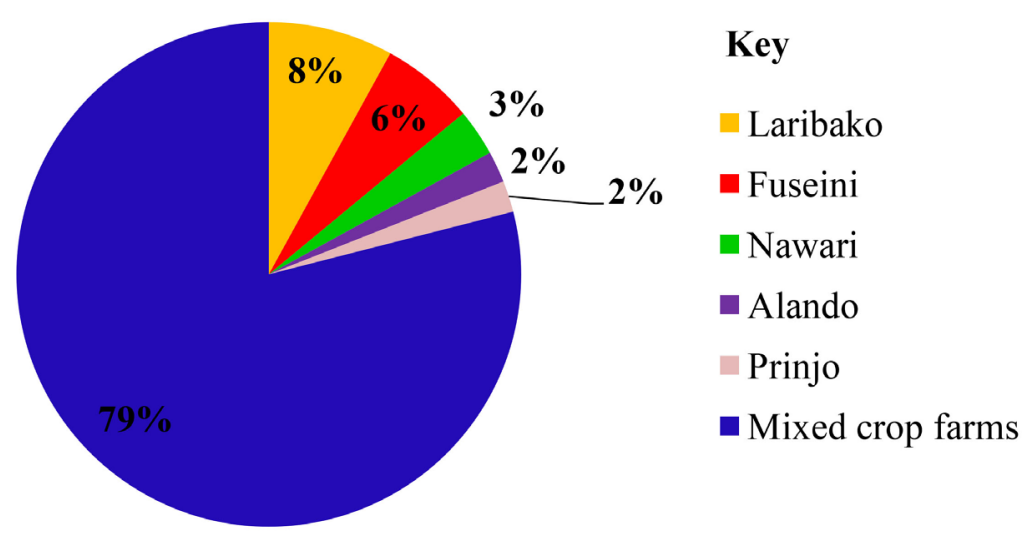

Figure 2. Types/varieties of yam cultivated by the farmers in the study area.

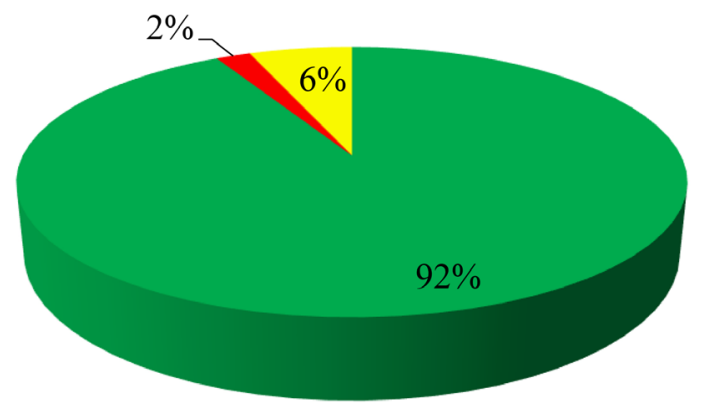

Key

Own money

- Money lenders

Bank loans

Figure 3. Farmers' sources of finance for yam production.

\subsubsection{Farm Size and Labour Availability}

Thirty four percent (34\%), forty eight percent $(48 \%)$, fourteen percent $(14 \%)$, and four percent (4\%) of the respondents had their farm sizes in the ranges of 1 5 ha, 6 - 10 ha, 11 - 15 ha, and 16 - 20 ha, respectively. Fifty four percent (54\%) of them used family labour while forty six percent (46\%) used hired labour. Seventy six percent $(76 \%)$ indicated that labour is not always available while twenty four percent (24\%) found labour availability to be satisfactory. Table 2 indicates the size ranges of respondents' farms and labour sources.

\subsubsection{Other Crops Cultivated Aside Yam, Sources of Planting Materials, Extension Officers' Visits, and Cooperative Organizations}

Ten percent (10\%) of the farmers cultivated sorghum alongside with yam. Twenty percent $(20 \%)$ cultivated cassava, twenty four percent $(24 \%)$ maize, nineteen percent (19\%) groundnut, and eight percent (8\%) beans. The remaining nineteen percent (19\%) cultivated other crops which were specified as pepper, millet, tomato, okra, and rice. Ten percent (10\%) of the respondents obtained their planting materials from family and friends, seventy eight percent (78\%) from farmers' own collection, and only twelve percent (12\%) from certified seed dealers. All respondents agreed that the few extension officers in the area visit them irregularly (once in two months or twice a year). None of the farmers belonged to any farmers' cooperative organization. Table 3 shows the other crops cultivated aside yam, and sources of planting materials. 
Table 2. Farm size and labour availability.

\begin{tabular}{ccc}
\hline & Number of farmers & Percent respondent (\%) \\
\hline Farm size (hectares) & 34 & 34 \\
$1-5$ & 48 & 48 \\
$6-10$ & 14 & 14 \\
$11-15$ & 4 & 4 \\
$16-20$ & 100 & 100 \\
Total & & \\
Source of labour & 46 & 46 \\
Hired labour & 54 & 54 \\
Family labour & 100 & 100 \\
Total & &
\end{tabular}

Table 3. Crops cultivated aside yam production and sources of planting materials.

\begin{tabular}{ccc}
\hline & Number of farmers & Percent respondent (\%) \\
\hline Other cultivated crops & 10 & 10 \\
Sorghum & 20 & 20 \\
Cassava & 24 & 24 \\
Maize & 20 & 20 \\
Groundnut & 8 & 8 \\
Beans & 18 & 18 \\
Others & 100 & 100 \\
Total & & \\
Sources of planting materials & 10 & 10 \\
Relatives and friends & 12 & 12 \\
Certified seed dealers & 78 & 78 \\
Farmers' own collection & 100 & 100 \\
Total & &
\end{tabular}

\subsection{Agronomic and Harvesting Practices}

\subsubsection{Cropping Type and Pattern, Farming Systems, and Soil Improvement}

Cropping types identified were intercropping, mixed-cropping, and mono-cropping. Majority $(80 \%)$ of the farmers practiced intercropping whiles ten percent (10\%) and another ten percent (10\%) practiced mono-cropping and mixedcropping respectively. Crop rotation was practiced amongst all respondents. All the farmers did both commercial and subsistence farming. None of the farmers did any soil improvement practice. Figure 4 shows the cropping types undertaken.

\subsubsection{Land Preparation, Tools/Equipment Involved, Field Practices, and Chemical Usage}

All farmers prepared mounds for yam cultivation. They indicated that mounds 


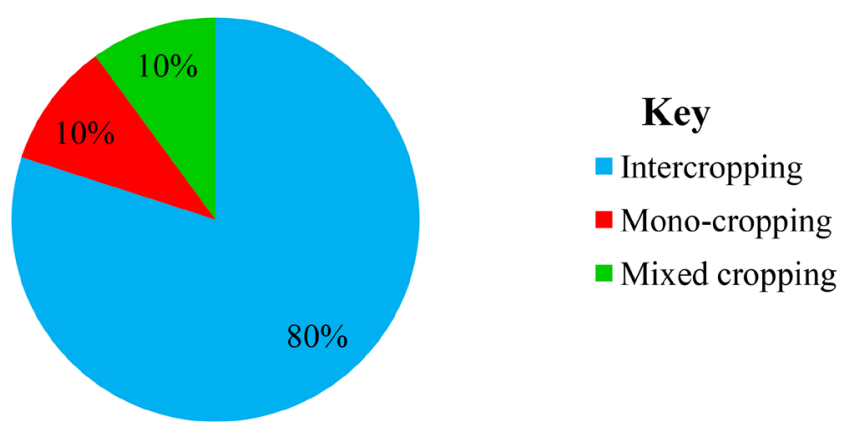

Figure 4. Cropping type practiced.

enhanced large and quality tuber production. The tools/equipment and machinery involved in land preparation were hoes, cutlasses, tractors, and bullocks. Ninety percent (90\%) of them used all the tools/equipment and machinery indicated in Figure 8 except bullocks whiles ten percent (10\%) used all. None of the farmers applied chemical fertilizers and pesticides but all applied weedicides after planting. None of the farmers used yam dressers (chemical/botanical treatment) on their yam sets before planting. Mulching, weeding, and staking were practiced amongst all farmers. Figure 5 shows the farmers' usage of tools and machinery during land preparation.

\subsubsection{Harvesting and Tools Involved}

Farmers did not have any particular time for harvesting yam; they harvested at any time of the day using hoe, machete, or earth chisels where applicable. Twenty two percent (22\%) of the farmers used hoe, twenty percent (20\%) used machete, forty eight percent (48\%) used more than one of the tools, and ten percent (10\%) used the earth chisel. Majority (88\%) of the farmers indicated that they had problems (cuts, punctures, and abrasions on the tubers) with the tools whiles twelve percent (12\%) found them to be satisfactory. All respondents agreed that they harvested at both dry-leaf and fresh-leaf stages. Figure 6 shows the tools farmers used for harvesting.

\subsubsection{Pests and Diseases Encountered in the Field}

All respondents pointed out that there were incidences of pests (termites, rodents, mealybugs, and yam beetles) and diseases (tuber rot and yam mosaic) occurrences on their yam fields. Ninety one percent (91\%) of them reported the incidence of rodents and tuber rot, fifty nine percent (59\%) mentioned termites and mealybugs, thirty two percent (32\%) and twelve percent (12\%) mentioned yam beetles and yam mosaic, respectively. Figure 7 shows the responses to the occurrences of pests and diseases.

\subsubsection{Curing of Yam Produce and Problems Associated with Harvesting}

None of the respondents did curing after harvest. Twelve percent (12\%) of the farmers reported that yam required much care which made harvesting tedious. Twenty two percent (22\%) of them reported on harmful organisms like snakes 


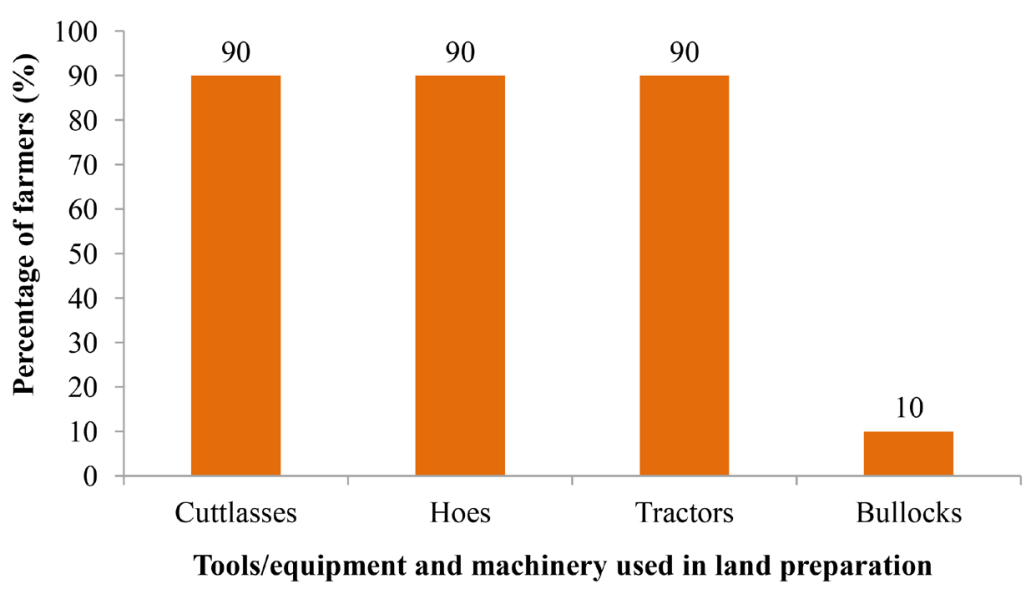

Figure 5. Tools/equipment and machinery used for land preparation.

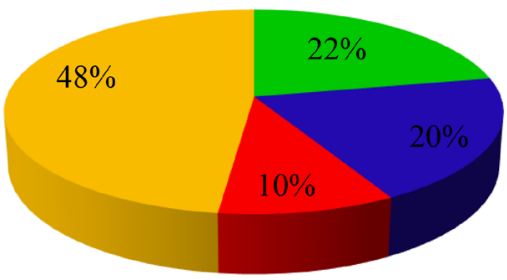

\section{Key}

Hoe

Machete

Earth chisel

More tha one of the tools above

Figure 6. Tools used by the farmers for harvesting yam.

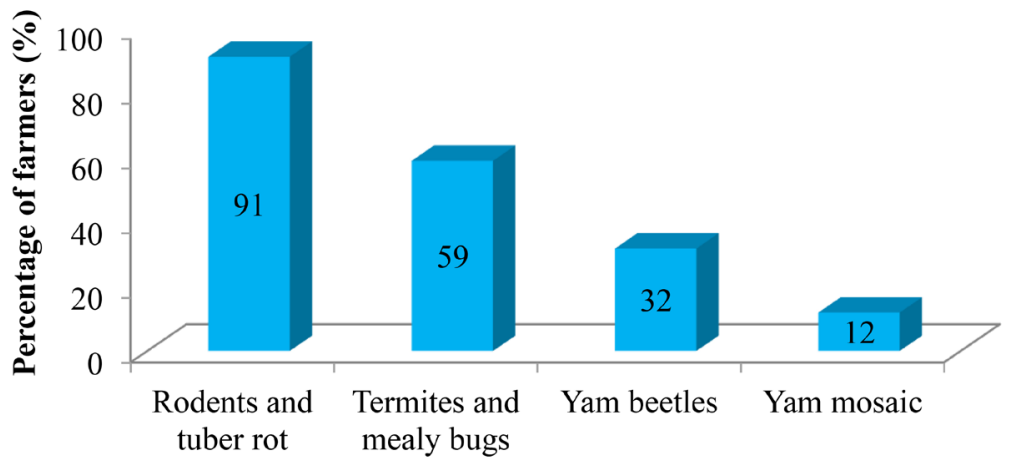

Diseases/insects encounted on the field

Figure 7. Farmers' reports on incidence of diseases and pests in the field.

and scorpions while sixty six percent (66\%) mentioned both the harmful organisms and the tedious nature of yam harvests. Figure 8 shows the problems associated with yam harvesting.

\subsection{Storage and Marketing Practices of Yam by Producers in the Study Area}

\subsubsection{Marketing of Yam by Producers}

The resident market place, farm gate, and their homes were identified as the 


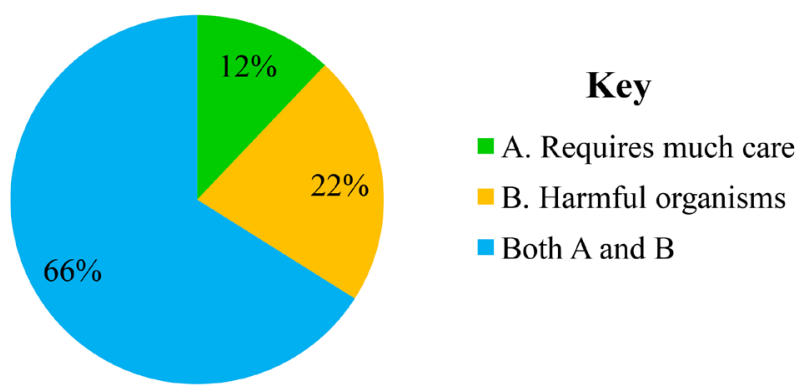

Figure 8. Problems associated with yam harvesting.

places farmers usually marketed their yam produce. Eighty four percent $(84 \%)$ of them sold their produce at the resident market place, ten percent $(10 \%)$ at the farm gate, and six percent (6\%) at their homes. All the farmers did commercial yam sales to middle men. Farmers also indicated that the unit of sale was by count (number/quantity). However, the cost per unit was uncertain since prices depended on size, count, and variety/cultivar; and prices were not fixed for a particular quantity. All respondents indicated that yam was not sold sometimes because of the absence of buyers. They added that yam was abundant during the dry season. Figure 9 shows farmers' marketing places of yam in the study area.

\subsubsection{Storage of Yam by Producers}

All respondents reported that they stored yam after harvest. Ways by which the farmers stored their produce included harvested and stored in situ, tied up in barns, placed on wooden platforms raised above the ground level to keep them dry, placed in shallow trenches and covering them with dry loose soil, dressed with ashes in packages and covered with soil, and then piled in pyramidal shapes and covered with palm leaves (leaving a hole in the middle for ventilation). Farmers did not stick to only one way of storing their yam produce. They practiced more than one of the above methods of storage.

Forty one percent $(41 \%)$ of them stated that yam was stored to sell in the lean season. Twenty eight percent (28\%) stated that yam was stored sometimes due to lack of buyers while twenty percent (20\%) and eleven percent (11\%) stored their yam as a result of lack of means of transport and to avoid spoilage, respectively. Figure 10 shows farmers' reasons for storing yam. All respondents indicated that they stored seed yam (yam setts) meant for the following yam production season.

\subsubsection{Storage Structures for Fresh Yam Produce}

All respondents ever stored yam in shallow dug trenches. They indicated that the quantity of tubers the structure could contain depended on size of the tubers and on the depth and width of the dug trench and hence had no specific number of tubers it could contain. All the farmers indicated that fresh yam is produced and stored in the rainy season by temporally burying yam produce in shallow trenches as the storage structure. None of the farmers indicated any protective treatment given to the yam produce before storage. The problems and health disorders of 


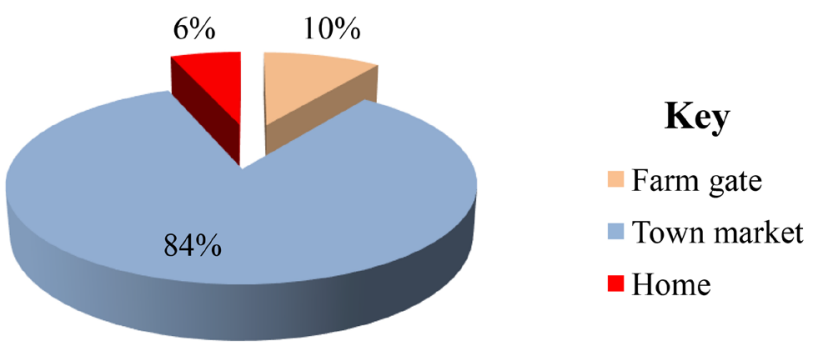

Figure 9. Site for yam sales by farmers in the study area.

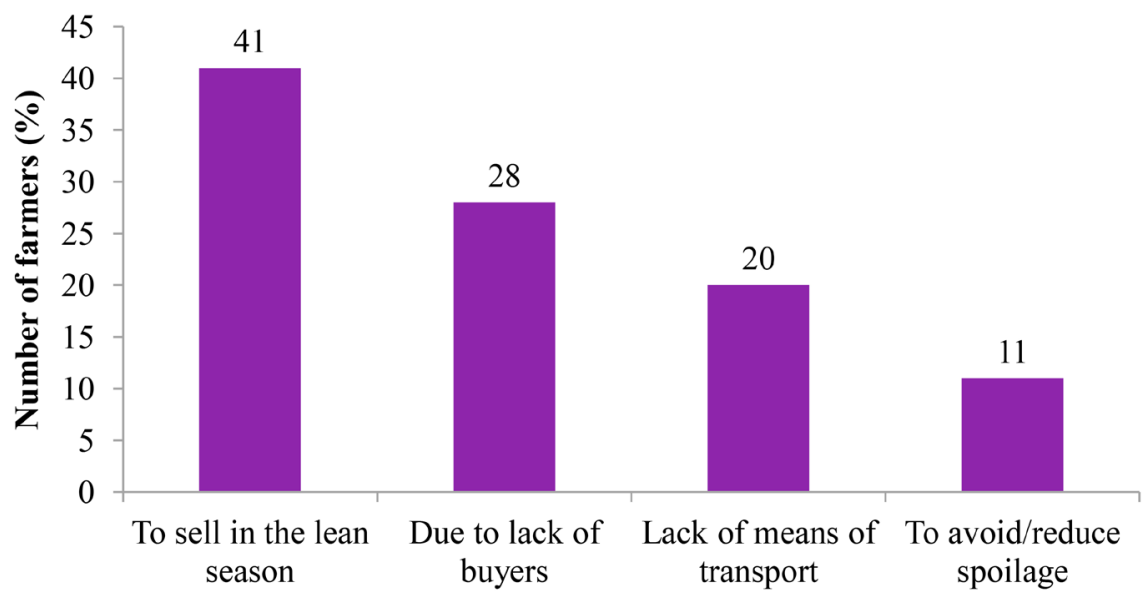

Reasons why yam produced are stored by the farmers

Figure 10. Reasons why farmers in the study area store their yam produce.

tubers in storage were identified as pests/rodents attack, rotten tubers, and structures' failure to keep the produce for longer times i.e. poor structures. All the farmers reported that yam infections were noticed on the field and in storage. Figure 11 shows the problems associated with farmers' shallow trenches storage structure.

\subsubsection{Storage Structures for Dry Yam Produce}

All the farmers stored their dry yam produce in barns and on wooden platforms. They all agreed that these structures had no specific storage capacity and hence depended on the construction size. Majority (90\%) of the farmers reported that they preferred barn storage facility whiles the remaining ten percent $(10 \%)$ preferred wooden platform storage facility. Forty eight percent (48\%) of the farmers stored their yam for a period of 5 - 6 months while fifty two percent (52\%) stored their yam for 7 - 8 months. Ninety percent (90\%) do inspection of produce in storage once a while and the remaining ten percent (10\%) inspect their produce only when they are ready to sell. The problems of the storage structures were identified as hosts of pests/rodents/insects, diseases/tuber rot, and harmful organisms like snakes and scorpions. Nineteen percent (19\%) of the farmers reported on pests/rodents/insects, twenty three percent (23\%) on diseases/tuber rot, twelve percent (12\%) on harmful organisms like snakes and scorpions, 
whiles the remaining forty six percent (46\%) reported on all the mentioned problems. Figure 12 and Figure 13 show farmers' preferred storage structures and the problems of storage, respectively.

\section{Discussion}

Farmers in the study area were quite old with majority of them falling within the ages of 31 - 40 years (34\%) followed by $41-50$ years (30\%). This result was in line with the findings by Hudu et al. [16] and Kwara [11] who reported that yam farmers in the North Eastern corridor of Northern Ghana were quite old with a mean age of 40.48 years. All respondents were males which confirm early findings by Adam et al. [15] and recently by Kwara [11] who reported that yam production in Northern Ghana was a male dominated enterprise with a probable reason that yam production was more labour intensive when compared to the production of other crops. Djana et al. [12] reported that not all available family labour was involved in yam production but that men were more involved when investigations were conducted in Ghana and Nigeria.

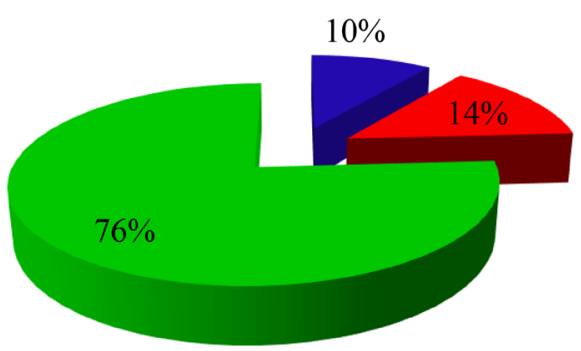

Key

Figure 11. Problems associated with farmers' shallow trenches used for yam storage.

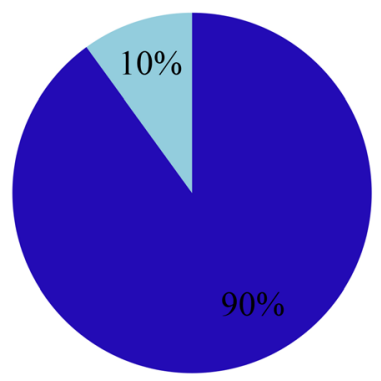

\section{Key}

- Barns storage structure

Wooden platforms

Figure 12. Farmers' preferred storage structures.

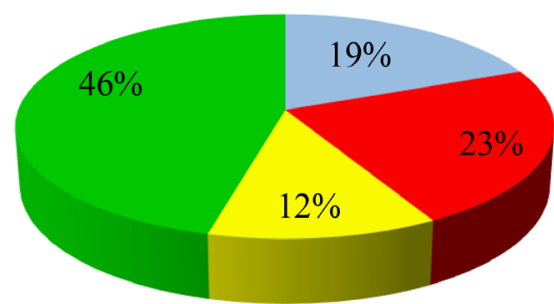

\section{Key}

- Pest/rodents/insects

- Diseases/tuber rot

Harmful organisms

- All above

Figure 13. Problems with storage of yam produce. 
Majority (44\%) of the farmers did not have any form of education and only twelve percent (12\%) made it to the tertiary level whiles the rest were found between basic and senior high school levels. The results showed a high level of illiteracy among yam farmers in the area. Adam et al. [15] reported earlier that the educational status of farmers in the North eastern corridor of Northern Ghana was highly illiterate and further opined that such high illiteracy may have a significant impact on the levels of adoptions of new technologies in yam production.

Laribako, Limo, Fuseini, Prinjo, Nawari (water yam), Alando, Akaba, Baatoo, Nyame-Nti, Afayili, Baffoo, and Pona varieties/cultivars of yam were discovered in the study area. This discovery was reiterated by Kwara [11] who also stated that the names of the cultivars as indicated were only recognised by the people of a particular geographical location and could be known by different names elsewhere. The most popular varieties were Laribako, Fuseini, Alando, Prinjo, and Nawari which were mostly cultivated in combination with others on the same farm. Cultivating one variety alone on the same farm was unusual among the farmers. The choice of these cultivars was influenced by the availability of the cultivar, high yielding ability, and market demand (with particular reference to taste and appearance) [12]. Barnabas [19] and Amegbeto et al. [20] indicated that consumer preference may help in designing new crop varieties and crop management systems that simultaneously satisfy the needs of farmers and the consumers alike. The authors added that it may also aid in the determination of relevant quality attributes of the product as asserted by Zaknayiba and Tanko [9].

Majority of the farmers indicated that they used their own monies in farming but was usually insufficient; a situation that could result in absence of adequate funding for required farm inputs. Agricultural extension services officers visited the farmers quite irregularly with the consequence of a few or no extension officer-farmer interactions which would have informed the low rate of adoption of technologies amongst respondents. Majority of farm sizes were in the range of 6 10 hectares per head and labour availability turned out to be a major problem but contrary to this, Djana et al. [12] reported that hired labour for yam production was prominent in Ghana and Nigeria. Majority of the farmers used their own yam sets than purchased or certified yam sets following reports by Djana et al. [12] who stated that farmers in Ghana and Nigeria mostly used own-produced yam sets. The authors attributed this to unavailability or cost of the yam sets and that the consequences could be low productivity.

Zaknayiba and Tanko [9] reported that yam is produced in Ghana with unsophisticated inputs. This is demonstrated by little or no usage of sophisticated inputs in this study, probably due to unavailability of new technologies, cost of equipment, or farmers' poor attitude towards adoption. All farmers prepared mounds for yam production which they believed enhanced larger and quality tubers. Staking and weeding were their common practices after planting which 
were said to be necessary for optimal exposure of the yam plants' leaves to sunlight for healthy plant growth and productivity, more especially in yam varieties with climbing vines [4].

Harvesting was done at any time of the day with common simple tools like cutlasses, hoes, earth chisels, and sticks but with problems of cuts, punctures, and abrasions on vulnerable tubers. Curing was not done after harvesting which may have led to the rotting of tubers encountered during the study. Curing is essentially a wound healing operation to replace the damaged periderm prior to storage of yam. Yam tubers therefore need to be properly cured according to recommended procedures as soon as possible after harvest to enable the formation of a cork layer over the surface for protection against micro-organism infection and excessive water loss which enhances shelf life of the tuber [21].

Majority of the farmers' yam produce, particularly on commercial scales were sold to middle men in the resident market. Due to high cost of transportation as influenced by bad road networks and associated problems, farmers found it difficult transporting their produce to the urban market centres where demand was high. Barnabas [19] indicated that transportation played an important role in the distribution of agriculture produce in Ghana and that it helped in creating market for agriculture produce and reduced spoilage and wastage of farm produce.

In the rainy season when fresh yam is harvested it is stored in shallow trenches but for temporal purposes. For dry season when more yam is harvested, majority of the farmers store for up to 6 - 7 months in barns and on wooden platforms: the barn being the most preferred in West Africa [21] [22]. Yam storage techniques seem to be limited among the farmers and may be due to insufficient services of agriculture extension officers. Farmers need to understand that only sound and healthy yam tubers are suitable for storage. As a result of this yam is harvested with great care but because of its perishable nature some will get damaged accidentally and need to be isolated for curing or put to immediate use. Farmers suffered technological knowledge gaps since none of them seemed to be aware of curing of yam, the use of chemical or botanical treatments, and other storage techniques or procedures for the yam tuber prior to storage.

\section{Conclusions and Recommendations}

Ages of respondents were in the range of 11 to over 60 years with illiterate majority which was a threat to productivity. They were inadequate in their knowledge on agronomic, harvest, and postharvest practices and techniques that enhance health and shelf life of yam.

Farmers suffered technological knowledge gaps since none of them seemed to be aware of curing of yam, the use of chemical or botanical treatments, and other storage techniques or procedures for the yam tuber prior to storage. They kept their fresh yam produce in shallow dug trenches where temporal storage was the target but stored their dry yam produce intended for long periods in barns (most preferred) and on wooden platforms. Barns and wooden platforms were more 
sustainable but with a little preponderance of the former.

Causes of health disorders and associated problems in store were insect pests, rodents, weed pests, diseases/tuber rot, yam beetles, snakes, scorpions, and the inability of some storage structures to keep produce for a long time.

Research, government, and other stakeholder institutions should partner up and make improved and certified yam sets accessible and affordable, and intensify agriculture extension services' interventions that empower farmers the knowledge on agronomic, harvest, and postharvest practices and techniques.

\section{Acknowledgements}

The authors are thankful to the farmers who were willing to participate in the study.

\section{Conflicts of Interest}

The authors declare no conflicts of interest regarding the publication of this paper.

\section{References}

[1] Oni, M.O. and Omoniyi, A.O. (2012) Studies on Temperature Influence on Oviposition and Development of Immature Stages of the Yam Beetle Dinoderus porcellus Lesne. Coleoptera: Bostrichidae on Dried Yam Species. Journal of Agricultural Science, 4, 213-218. https://doi.org/10.5539/jas.v4n2p213

[2] Mignouna, D.B., Akinola, A.A., Suleman, I., Nweke, F. and Abdoulaye, T. (2014) Yam: A Cash Crop in West Africa. YIIFSWA Working Paper Series No. 3. Yam Improvement for Income and Food Security in West Africa, International Institute of Tropical Agriculture, Ibadan, $46 \mathrm{p}$.

[3] Maroya, N.G., Asiedu, R., Kumar, P.L., Lopez-Montes, A., Orchard, J. and Ndiame, F. (2014) YIIFSWA Project Description: YIIFSWA Working Paper Series No. 1. Yam Improvement for Income and Food Security in West Africa. International Institute of Tropical Agriculture, Ibadan, 18.

[4] Christian, A. and Olugbenga A. (2016) Yam (Dioscorea spp). In: Thomas, B., Murray, B.G. and Murphy, D.J., Encyclopedia of Applied Plant Sciences, Second Edition, Vol. 3, Academic Press, Cambridge, 435-441. https://doi.org/10.1016/B978-0-12-394807-6.00177-5

[5] Ackah, D., Agboyi, M.R. and Adu-Gyamfi, L. (2014) An Investigation of Yam Ingestion Customs in Ghanaian Urban Communities, Ghana. International Journal of Sciences. Basic and Applied Research, 17, 374-411.

[6] Ibitoye, S.J. and Onimisi, J.A. (2013) Economic Assessment of Yam Production in Kabba-Bunu Local Government Area of Kogi State, Nigeria. Journal of Development and Agricultural Economics, 5, 470-475. https://doi.org/10.5897/JDAE2013.0484

[7] Tetteh, J.P. and Saakwa, C. (1991) Prospects and Constraints to Yam Production in Ghana. Proceedings of the 9 th Symposium of the International Society for Tropical Root Crops, Accra, 20-26 October 1991, 355-359.

[8] Ibitoye, S.J. and Attah, E.S. (2012) An Assessment of Yam Mini-Sett Utilization and Profit Level in Kogi State, Nigeria. International Journal of Applied Research and 
Technology, 1, 3-11.

[9] Zaknayiba, D.B. and Tanko, L. (2013) Costs and Returns Analysis of Yam Production among Small Scale Farmers in Karu Local Government Area, Nasarawa State, Nigeria. Production Agriculture and Technology, 9, 73-80.

[10] Ohene-Yankyera, K., Aidoo, R. and Ohenewah-Tawiah, E. (2011) Effects of Real Exchange Rate and Gross Domestic Product (GDP) on Yam Exports in Ghana. Botswana Journal of Agriculture and Applied Sciences, 7, 57-63.

[11] Kwara, F.A. (2019) Possible Cause(s) of Health Disorders in Stored Yam at the Farm Gate. MSc Thesis Submitted to the School of Graduate Studies, University for Development Studies, Tamale, 101.

[12] Djana, B.M., Adebayo, A.A., Tahriou, A. and Arega, A. (2015) Factors Influencing the Use of Selected Inputs in Yam Production in Nigeria and Ghana. Journal of Agriculture and Rural Development in the Tropics and Subtropics, 116, 131-142. http://nbn-resolving.de/urn:nbn:de:hebis:34-2015061048499

[13] Food and Agriculture Organization of the United Nations (2013) FAO Statistics. http://www.fao.org/statistics/en/

[14] Rees, D. (2012) Improving the Marketing System for Yams in Ghana. Natural Resources Institute, University of Greenwich, London.

[15] Adam, H., Zakaria, H. and Abujaja, A.M. (2014) Sociocultural Implications on Innovation Adoption: The Case of Adoption of Yam Minisett Technology among Farmers in Northern Region, Ghana. Journal of Agriculture Economics, Extension and Rural Development, 1, 105-113.

[16] Hudu, Z., Abujaja, A., Adam, H. and Yakubu, S. (2015) Does Gender Makes Livelihood Diversification? Evidence from Northern Ghana. International Gender of Agriculture Development Studies, 1, 36-51.

[17] Casley, D.J. and Lury, D.A. (1981) Data Collection in Developing Countries. The IDS Bulletin, 12, 55. https://doi.org/10.1111/j.1759-5436.1981.mp12004011.x

[18] SAS Institute (2004) SAS/SHARE fi 9.1 User's Guide. SAS Institute Inc., Cary.

[19] Barnabas, G. (2017) Effect of Transportation on the Marketing of Agriculture Products in Jos North. Journal of Research in Business and Management, 5, 99-106.

[20] Amegbeto, N.K., ManYong, V.M., Coulibaly, O. and Asiedu, R. (2008) Estimating Market Demand for Fresh Yam Characteristics Using Contingent Valuation: Implications for Crop Breeding and Production Choices. Agricultural Economics, 39, 349-363. https://doi.org/10.1111/j.1574-0862.2008.00338.x

[21] FAOSTAT (Food and Agriculture Organization Corporate Statistical Database) (2017) Yam Production in 2014. Crops/Region/World/Production Quality; from Pick List.

[22] Mijinyawa, Y. and Alaba, J.O. (2013) A Comparative Analysis of Barn and Platform as Storage Structures for Yam Tuber in Ibadan, Nigeria. African Journal of Agricultural Research, 8, 4115-4121. https://doi.org/10.5897/AJAR08.369 